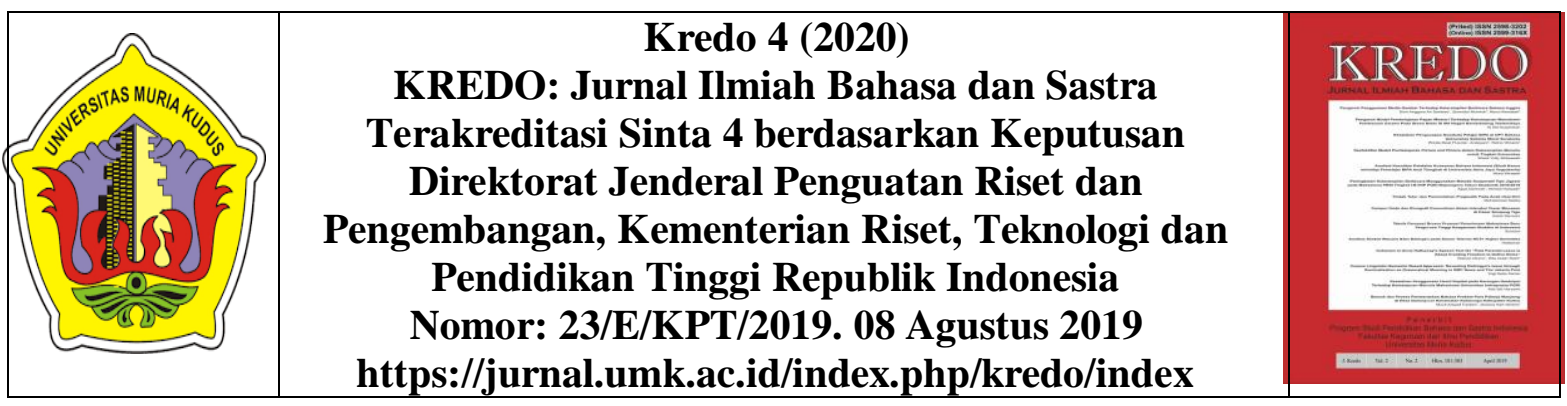

\title{
ANALISIS TERJEMAHAN PROFIL PERUSAHAAN ASING DI WIKIPEDIA INDONESIA
}

\author{
Herninda Cintia Kemala Sari \\ hernindacintia22@gmail.com \\ Universitas Airlangga, Indonesia
}

Info Artikel
Sejarah Artikel
Diterima
21 Mei 2020
Disetujui
20 September 2020
Dipublikasikan
28 Oktober 2020
Keywords profile,
company wikipedia.
translation, wi
Kata Kunci
profil perusahaan,
terjemahan, wikipedia.

Info Artikel $:$ :

The online encyclopedia Wikipedia has become a reference for internet users who need basic information about terms, events, characters, and company profiles. However, it is often found that online encyclopedia informational texts use foreign languages. Therefore, the role of the translator is very important to transfer this information. In particular, the translation of profiles of large companies, both private and state-owned, Indonesia. Translation is very important because it contains a variety of important information related to the company. This study aims to explore the translation phenomenon and the translation techniques used by Indonesian Wikipedia translators. The research method used is a qualitative descriptive method. Based on data analysis, it was found that the analysis of the Indonesian Wikipedia translation of the profile text of foreign companies : operating in Indonesia, namely British Petroleum, Unilever and Honda, used nine translation techniques and the translation results in Indonesian tended to be shorter and denser than the original text in Wikipedia with the language English. This shows a lot of reduction in information

: that the translators feel is excessive. However, this reduction does not affect the main information of the three foreign companies that are also established in Indonesia..

Abstrak

Ensiklopedia online Wikipedia telah menjadi rujukan para pengguna internet yang membutuhkan informasi dasar tentang istilah, peristiwa, tokoh, hingga profil perusahaan. Namun, sering dijumpai teks informasi ensiklopedia online menggunakan bahasa asing. Oleh sebab itu, peran penerjemah sangat penting untuk alih informasi tersebut. Khususnya terjemahan profil perusahaan-perusahaan besar, baik swasta maupun milik negara Indonesia. Penerjemahan sangat penting dilakukan mengingat di dalamnya terdapat beragam informasi penting terkait perusahaan tersebut. Penelitian ini bertujuan mengekplorasi fenomena penerjemahan serta teknik penerjemahan yang digunakan oleh penerjemah Wikipedia Indonesia. Metode penelitian yag digunakan adalah metode deskriptif kualitatif. Berdasarkan analisis data, ditemukan bahwa analisis terjemahan Wikipedia Indonesia terhadap teks profil perusahaan asing yang beroperasi di Indonesia, yaitu British Petroleum, Unilever dan Honda menggunakan sembilan teknik terjemahan dan hasil terjemahan dalam bahasa Indonesia cenderung lebih singkat dan padat dibandingkan dengan teks asli dalam Wikipedia dengan bahasa Inggris. Hal ini menunjukkan banyak pengurangan informasi yang dirasa berlebihan oleh penerjemah. Namun demikian pengurangan ini tidak mempengaruhi informasi utama ketiga perusahaan asing yang juga berdiri di Indonesia tersebut.

\section{PENDAHULUAN}

Di era industri 4.0 saat ini, penggunaan internet telah menjadi bagian dari masyarakat, khususnya di Indonesia. Banyak kebutuhan maupun keingintahuan masyarakat yang dapat dengan mudah dipenuhi melalui jejaring internet. Salah satunya kebutuhan akan informasi maupun ilmu pengetahuan dalam skala nasional dan internasional.
Informasi dan ilmu pengetahuan ini biasanya mudah didapat dari sebuah ensiklopedia online.

Namun demikian, tidak jarang ensiklopedia online menggunakan bahasa asing. Di sini peran penerjemah sangat penting untuk alih informasi dan ilmu pengetahuan tersebut. Sehingga tidak sedikit juga dapat ditemukan ensiklopedia online yang telah menerjemahkan informasi atau ilmu

184 | Jurnal Kredo

Vol. 4 No. 1 Oktober 2020 


Kredo 4 (2020)
KREDO: Jurnal IImiah Bahasa dan Sastra
Terakreditasi Sinta 4 berdasarkan Keputusan
Direktorat Jenderal Penguatan Riset dan
Pengembangan, Kementerian Riset, Teknologi dan
Pendidikan Tinggi Republik Indonesia
Nomor: 23/E/KPT/2019.08 Agustus 2019
https://jurnal.umk.ac.id/index.php/kredo/index

pengetahuan ke dalam beberapa bahasa tertentu. Salah satunya ensiklopedia online Wikipedia yang menyediakan beragam informasi atau ilmu pengetahuan dalam bahasa Inggris dan bahasa Indonesia.

Ensiklopedia online Wikipedia telah menjadi rujukan para pengguna internet yang membutuhkan informasi dasar dari sebuah istilah, peristiwa, tokoh, kebijakan publik, hingga profil perusahaan. Selain itu, Wikipedia memanfaatkan perangkat lunak Wiki yang sangat mengandalkan keterbukaan. Halaman Wiki dapat ditulis maupun disunting oleh siapa saja, sehingga setiap perubahan konten dapat dilihat oleh publik. Sifatnya desentralisasi dan tidak ada pengawas tunggal. Hingga saat ini, jumlah artikel di Wikipedia tumbuh menjadi 100.000 artikel versi bahasa Inggris.

Awalnya, Wikipedia diisi oleh para pengguna yang memiliki semangat berbagi ilmu pengetahuan melalui ensiklopedia online. Kekuatan Wikipedia yang bisa disunting oleh siapa saja kemudian dipandang sebagai kelemahan. Banyak pihak yang mendaftar ke sana, menulis, namun tidak didasarkan pada pengetahuan yang kuat. Hal ini membuat sejumlah pihak, terutama dari kalangan akademisi, menilai banyak artikel yang tidak akurat, bias, dan subjektif. Selain itu, Wikipedia juga diisi oleh konten artikel yang dinilai tidak layak ditayangkan dalam sebuah ensiklopedia.

Kendati mendapat banyak kritik, namun nyatanya, Wikipedia telah menjadi proyek ensiklopedia lintas bahasa terbesar dengan sekitar 73.000 editor aktif yang secara sukarela menjadi penjaga. Hingga saat ini, Wikipedia tersedia dalam 287 bahasa dan selalu masuk dalam jajaran situs web yang banyak dikunjungi di berbagai negara. Wikipedia bahasa Indonesia sendiri hadir sejak 30 Mei 2003 dan kini telah menghasilkan sekitar 349.000 artikel.

Selain bahasa Indonesia, Wikipedia juga menyediakan artikel dalam delapan bahasa daerah, yaitu Jawa, Sunda, Minang, Bugis, Banjar, Banyumasan, Aceh, dan Tetun (bahasa yang dituturkan di Timor Leste).

Di sisi lain, profil perusahaan merupakan wajah perusahaan untuk memperkenalkan diri lebih detail kepada publik tentang perusahaannya. Oleh karena itu, terjemahan profil perusahaan sangat penting dilakukan, khususnya pada perusahaan-perusahaan berskala besar, baik swasta maupun perusahaan milik negara di Indonesia. Profil perusahaan berskala internasional biasanya ditulis dalam dua bahasa.

Pertama, bahasa Inggis karena bahasa Inggris merupakan bahasa internasional. Kedua, dalam bahasa negara di mana perusahaan tersebut mengembangkan bisnis atau usahanya (ekspansi). Contohnya, profil perusahaan-perusahaan berskala internasional yang membuka cabang di Indonesia, maka profil perusahaan perusahaan tersebut akan ditulis ke dalam bahasa Inggris dan bahasa Indonesia. Mengingat begitu pentingya peranan profil perusahaan terhadap citra perusahaan tersebut, maka penerjemahan profil perusahaan tidak dapat dianggap sederhana. Hal ini dikarenakan profil perusahaan dapat memengaruhi pandangan mitra bisnis perusahaan terhadap perusahaan yang bersangkutan. 


Kredo 4 (2020)
KREDO: Jurnal IImiah Bahasa dan Sastra
Terakreditasi Sinta 4 berdasarkan Keputusan
Direktorat Jenderal Penguatan Riset dan
Pengembangan, Kementerian Riset, Teknologi dan
Pendidikan Tinggi Republik Indonesia
Nomor: 23/E/KPT/2019.08 Agustus 2019
https://jurnal.umk.ac.id/index.php/kredo/index

Oleh karena itu, dalam analisis penerjemahan profil perusahaan, khususnya terkait permasalahan istilah yang sesuai dengan bidang kerja perusahaan menjadi salah satu fenomena yang menarik untuk dianalisis dan dikaji guna bermanfaat bagi para penerjemah dalam menentukan strategi khusus agar dapat menentukan langkah-langkah dalam melakukan penerjemahannya dengan tepat.

Adapun tujuan utama kajian penerjemahan ini adalah untuk mengetahui teknik penerjemahan yang digunakan oleh penerjemah Wikipedia Indonesia dalam menerjemahkan teks dari Wikipedia Inggris. Selain itu juga menganalisis fenomena penerjemahan dan terjemahan yang terdapat di dalam teks profil perusahaan, dimana dalam penelitian ini akan mengkaji profil perusahaan British Petroleum, Unilever dan Honda, dimana ketiga perusahaan asing tersebut sudah lama mengembangkan usahanya ke berbagai negara termasuk beroperasi di Indonesia.

Sebelumnya, terdapat beberapa penelitian terkait profil perusahaan dan teknik penerjemahan istilah yang telah dilakukan oleh beberapa peneliti lain sebagai berikut.

Endang Purwaningrum dan Hastuti Redayanita (2016) dalam penelitiannya yang berjudul "Analisis Penerjemahan: Studi Kasus Pada Penerjemahan Company Profile." Hasil penelitian ini menunjukkan bahwa terdapat kompleksitas dalam metode terjemahan yang perlu tounderstand. Penelitian juga ini berisi hal-hal terkait penerjemahan istilah asing atau penyerapan dalam penerjemahan profil perusahaan.

186 | Jurnal Kredo Vol. 4 No. 1 Oktober 2020
Selain itu, juga pernah dilakukan Fitria Puji Nur Azizah (2019) dalam penelitiannya yang berjudul "Teknik Penerjemahan Kata-Kata Budaya pada Roman Das Parfum dari Bahasa Jerman ke dalam Bahasa Indonesia." Penelitian ini bertujuan untuk mengetahui bagaimana teknik penerjemahan yang digunakan untuk menerjemahkan katakata budaya pada roman bahasa Jerman Das Parfum dan novel terjemahannya dalam bahasa Indonesia yang berjudul Perfume. Hasil penelitian ini menunjukkan bahwa penerjemah menggunakan 15 teknik penerjemahan. Tiga diantaranya merupakan pencampuran dari dua teknik penerjemahan dalam satu data. Selain itu, data-data yang ditemukan tergolong ke dalam 10 kategori katakata budaya Espindola dan Vasconcellos (2006).

Penelitian ini akan mengidentifikasi kemudian mendeskripsikan analisis dari teks terjemahan Wikipedia bahasa Inggris ke Wikipedia bahasa Indonesia. Teks tersebut merupakan informasi terkait profil perusahaan multinasional yang beroperasi di Indonesia. Diantaranya British Petroleum, Unilever dan Honda.

Dalam penelitian ini juga akan dilakukan identifikasi teknik-teknik terjemahan yang digunakan Wikipedia Indonesia dalam mendeskripsikan ketiga perusahaan tersebut. Sehingga dapat diketahui sejauh mana penerjemah Wikipedia bahasa Indonesia dapat melakukan alih informasi sudah mampu mengkafer seluruh informasi yang dibutuhkan dan hasilnya tepat sasaran atau tidak.

Objek penelitian dalam artikel ini adalah profil perusahaan British 


Kredo 4 (2020)
KREDO: Jurnal IImiah Bahasa dan Sastra
Terakreditasi Sinta 4 berdasarkan Keputusan
Direktorat Jenderal Penguatan Riset dan
Pengembangan, Kementerian Riset, Teknologi dan
Pendidikan Tinggi Republik Indonesia
Nomor: 23/E/KPT/2019.08 Agustus 2019
https://jurnal.umk.ac.id/index.php/kredo/index

Petroleum, Unilever dan Honda yang merupakan perusahaan asing yang sudah lama mengembangkan usahanya ke berbagai negara termasuk beroperasi di Indonesia.

Umumnya, profil ketiga perusahaan tersebut menggunakan bahasa Inggris dalam memberi deskripsi tentang perusahaannya. Seperti diketahui bersama, bahasa Inggris merupakan bahasa internasional dan digunakan sebagai bahasa komunikasi global oleh hampir seluruh negara anggota perserikatan bangsa-bangsa (PBB). Namun, Wikipedia juga menyediakan deskripsi ketiga perusahaan tersebut dalam bahasa Indonesia. Hal ini diperoleh dengan menerjemahkkan teks informasi perusahaan dari bahasa Inggris ke dalam bahasa Indonesia.

Oleh sebab itu, penelitian ini sangat menarik untuk dibahas mengingat begitu pentingnya perananan profil perusahaan dalam membangun image daripada perusahaan tersebut. Sehingga, dalam penerjemahannya tidak dapat dianggap sederhana. Diperlukan adanya teknik penerjemahan tertentu agar informasi yang disampaikan sesuai dengan informasi dalam teks asli. Selain itu, kajian penelitian ini menarik untuk diteliti seiring dengan eksistensi Wikipedia yang masih terus digunakan sebagai salah satu sumber referensi.

\section{KAJIAN TEORI}

Penerjemahan tidak dapat dilakukan tanpa adanya landasan dasar yang berfungsi sebagai acuan dalam melakukannya. Sehingga, dalam pengerjaannya dibutuhkan adanya pendekatan dan teori tertentu yang dikemukakan oleh pakar atau ahli di bidang penerjemahan. Sedangkan keberhasilan suatu penerjemahan sangat tergantung pada tujuan dari dilakukannya penerjemahan. Hal ini dikarenakan hasil dari penerjemahan merefleksikan kebutuhan orang yang memerlukannya. Seperti penerjemahan sebuah artikel ilmiah. Biasanya dibutuhkan perhatian lebih dan kehatihatian dalam menentukan maknanya, sedangkan dalam aspek lainnya tidak dilakukan dengan demikian. Misalnya seperti dalam aspek bentuk estetikanya.

Menurut Newmark (1988), masalah penerjemahan terkait dengan perbedaan kebudayaan berupa gaya bahasa, latar, tema, seperti nama karakter, nama tempat, dan kata atau ungkapan budaya yang tidak ditemukan dalam bahasa sasaran. Oleh sebab itu, penerjemah dituntut untuk memiliki pengetahuan budaya sumber (TSu) supaya hasil terjemahannya tepat dan dapat dipahami oleh pembaca (TSa).

Namun demikian, dalam prosesnya terdapat beberapa hambatan yang tidak dapat dihindari. Hambatan-hambatan ini pun sering dijumpai. Misalnya, kesulitan dalam proses penerjemahan pada saat pencarian padanan atau ekuivalensi yang sesuai antara bahasa sumber (BSu) dan bahasa sasaran (BSa). Dalam hal ini, penerjemah dituntut lebih memahami pada tataran ekuivalensi untuk menghasilkan terjemahan yang tepat.

Oleh karena itu, dalam praktik menerjemahkan, sebagai realisasi dari proses penerjemahan selalu melibatkan pencarian padanan. Apabila padanan telah ditemukan, setiap unsur bahasa yang dipadankan itupun masih terbuka untuk berbagai penafsiran. 


Kredo 4 (2020)
KREDO: Jurnal IImiah Bahasa dan Sastra
Terakreditasi Sinta 4 berdasarkan Keputusan
Direktorat Jenderal Penguatan Riset dan
Pengembangan, Kementerian Riset, Teknologi dan
Pendidikan Tinggi Republik Indonesia
Nomor: 23/E/KPT/2019.08 Agustus 2019
https://jurnal.umk.ac.id/index.php/kredo/index

Sedangkan Pym (2014) menyebutkan kesepadanan. Tidak mengatakan bahwa bahasa adalah sama. Hal ini dikarenakan ekuivalensi atau kesepadanan yang bisa sama adalah nilainya. Ekuivalensi sering digunakan sehingga sering ditemukan dalam fase penerjemahan. Khususnya dalam aspek menentukan struktur atau makna, dimana secara keseluruhan dari teks bahasa sumber berbeda, namun masih sama situasi komunikasinya. Penerjemahan yang dilakukan dengan metode ekuivalensi atau kesepadanan, berfokus pada fungsi suatu unit linguistik yang sepadan. Hal ini sering dijumpai ketika penerjemah sedang menerjemahkan teks berbentuk idiom, peribahasa, ucapan selamat dan lain-lain.

Sementara, Molina dan Albir (2002) mengatakan teknik penerjemahan merupakan cara untuk mempermudah proses penerjemahan yang dilakukan oleh penerjemah dalam menerjemahkan. Khususnya pada tataran unsur mikro. Molina dan Albir mengklasifikasikan teknik penerjemahan menjadi delapan belas, yang terdiri dari adaptasi, penambahan, peminjaman, kalke, kompensasi, deskripsi, kreasi diskursif, padanan lazim, generalisasi, amplifikasi linguistik, kompresi linguistik, penerjemahan harfiah, modulasi, partikularisasi, reduksi, subtitusi, transposisi, dan variasi.

Berbeda dengan teknik dalam penerjemahan film. Di dalam prosesnya, terdapat dua jenis kegiatan penerjemahan, yaitu dubbing atau sulih suara dan subtitling. Khusus pada subtitling, tantangan dalam penerjemahan film terdapat pada keterbatasan waktu yang ditentukan dan 188 | Jurnal Kredo Vol. 4 No. 1 Oktober 2020 jumlah karakter yang ditentukan untuk menampilkan tulisan atau subtitle di dalam layar.

Dalam penerjemahan, seorang penerjemah dituntut untuk mendapatkan kata-kata yang sepadan sehingga terjemahan yang dihasilkan menjadi akurat. Sedangkan dalam memproduksi subtitle, terdapat berbagai macam problematika penerjemahan yang ditemui. Seperti adanya beberapa peraturan yang harus disepakati mulai dari kesesuaian hasil terjemahan, kesesuaian panjang pendek kalimatnya, kelayakan terbit apakah sudah sesuai dengan budaya yang berlaku di tempat target dan lain sebagainya.

Sementara, menurut Fotios Karamitroglou (2000) konsep penerjemahan subtitle meliputi norma, transkripsi, kode, dan narasi yang terdiri dari agen manusia, produk, penerima, mode, institusi, dan pasar.

\section{METODE PENELITIAN}

Penelitian ini disusun menggunakan desain pendekatan deskriptif kualitatif. Moloeng (2004) mendefinisikan penelitian kualitatif sebagai sebuah penelitian yang dilakukan dengan tujuan untuk memahami secara mendalam terkait subjek penelitian dan memahami fenomena sosial secara mendalam dengan mengembangkan teori berdasarkan data yang ditemukan.

Namun demikian, analisis data diuraikan secara deskriptif komparatif, yang mana dilakukan perbandingan antara teks sumber (TSu) dan teks sasaran (TSa).

Data dan sumber data penelitian diperoleh dari website Wikipedia Inggris 


Kredo 4 (2020)
KREDO: Jurnal IImiah Bahasa dan Sastra
Terakreditasi Sinta 4 berdasarkan Keputusan
Direktorat Jenderal Penguatan Riset dan
Pengembangan, Kementerian Riset, Teknologi dan
Pendidikan Tinggi Republik Indonesia
Nomor: 23/E/KPT/2019.08 Agustus 2019
https://jurnal.umk.ac.id/index.php/kredo/index

dan Indonesia yang berisi teks terjemahan profil perusahaan British Petroleum, Unilever dan Honda di Wikipedia Indonesia.

Metode analisis data dalam penelitian ini dimulai dari pengumpulan data. Data penelitian berupa teks profil perusahaan yang disajikan oleh Wikipedia online. Baik disajikan dalam bahasa Inggris dan bahasa Indonesia. Kemudian dibaca secara seksama. Dieksplorasi dengan teliti, disimak untuk selanjutnya dapat diidentifikasi adanya istilah-istilah khusus yang ada di dalam teks profil perusahaan tersebut. Meski memuat informasi yang sama, dapat ditemukan adanya perbedaan dalam kedua teks tersebut.

Adapun analisis terjemahan profil perusahaan pada Wikipedia Inggris dan Indonesia dilakukan dengan membandingkan isi informasi dari masing-masing website Wikipedia apakah memuat informasi yang sama persis atau tidak. Selanjutnya dilakukan identifikasi terhadap teknik penerjemahan yang digunakan setelah menyimak isi dari masing-masing website Wikipedia tersebut.

\section{HASIL DAN PEMBAHASAN}

Penelitian ini menganalisis data teks terjemahan berdasarkan jenis dan teknik terjemahan paling dominan menurut Molina dan Albir (2002). Dalam menganalisis jenis dan teknik penerjemahan tersebut, berikut dilampirkan tiga data berupa teks asli berisi informasi profil perusahaan dari Wikipedia Inggris yang kemudian diterjemahkan dan disajikan di Wikipedia Indonesia, yaitu profil perusahaan British Petroleum, Unilever dan Honda.

Berikut adalah teks informasi profil perusahaan British Petroleum yang disajikan Wikipedia Inggris.

"BP plc (formerly The British Petroleum Company plc and BP Amoco plc) is a British multinational oil and gas company headquartered in London, United Kingdom. It is one of the world's seven oil and gas supermajors, whose performance in 2012 made it the world's sixth-largest oil and gas company, the sixth-largest energy company by market capitalization and the company with the world's 12th-largest revenue (turnover). It is a vertically integrated company operating in all areas of the oil and gas industry, including exploration and production, refining, distribution and marketing, petrochemicals, power generation and trading. It also has renewable energy interests in biofuels, wind power and solar technology."

"As of 31 December 2018, BP had operations in nearly 80 countries worldwide, produced around 3.7 million barrels per day $(590,000 \mathrm{~m} 3 / \mathrm{d})$ of oil equivalent, and had total proven reserves of 19.945 billion barrels $(3.1710 \times 109$ m3) of oil equivalent. The company has around 18,700 service stations worldwide. Its largest division is BP America in the United States. In Russia, BP owns a $19.75 \%$ stake in Rosneft, the world's largest publicly traded oil and gas company by hydrocarbon reserves and production. BP has a primary listing on the London Stock Exchange and is a constituent of the FTSE 100 Index. It has secondary listings on the Frankfurt Stock Exchange and the New York Stock Exchange." 


Kredo 4 (2020)
KREDO: Jurnal IImiah Bahasa dan Sastra
Terakreditasi Sinta 4 berdasarkan Keputusan
Direktorat Jenderal Penguatan Riset dan
Pengembangan, Kementerian Riset, Teknologi dan
Pendidikan Tinggi Republik Indonesia
Nomor: 23/E/KPT/2019.08 Agustus 2019
https://jurnal.umk.ac.id/index.php/kredo/index

"BP's origins date back to the founding of the Anglo-Persian Oil Company in 1908, established as a subsidiary of Burmah Oil Company to exploit oil discoveries in Iran. In 1935, it became the Anglo-Iranian Oil Company and in 1954 adopted the name British Petroleum. In 1959, the company expanded beyond the Middle East to Alaska and it was one of the first companies to strike oil in the North Sea. British Petroleum acquired majority control of Standard Oil of Ohio in 1978. Formerly majority state-owned, the British government privatised the company in stages between 1979 and 1987. British Petroleum merged with Amoco in 1998, becoming BP Amoco plc, and acquired ARCO and Burmah Castrol in 2000, becoming BP plc in 2001. From 2003 to 2013, BP was a partner in the TNK-BP joint venture in Russia."

"BP has been directly involved in several major environmental and safety incidents. Among them were the 2005 Texas City Refinery explosion, which caused the death of 15 workers and resulted in a record-setting OSHA fine; Britain's largest oil spill, the wreck of Torrey Canyon in 1967; and the 2006 Prudhoe Bay oil spill, the largest oil spill on Alaska's North Slope, which resulted in a US\$25 million civil penalty, the largest per-barrel penalty at that time for an oil spill."

"The 2010 Deepwater Horizon oil spill, the largest accidental release of oil into marine waters in history, resulted in severe environmental, health and economic consequences, and serious legal and public relations repercussions for BP. 1.8 million US gallons $(43,000$ 190 | Jurnal Kredo Vol. 4 No. 1 Oktober 2020 bbl; 6,800 m3) of Corexit oil dispersant were used in the cleanup response, becoming the largest application of such chemicals in US history. The company pleaded guilty to 11 counts of felony manslaughter, two misdemeanors, one felony count of lying to Congress, and agreed to pay more than $\$ 4.5$ billion in fines and penalties, the largest criminal resolution in US history. On 2 July 2015 , BP and five states announced an \$18.7 billion settlement to be used for Clean Water Act penalties and various claims."

Berikut adalah teks informasi profil perusahaan British Petroleum yang disajikan Wikipedia Indonesia.

"BP atau bp (dulunya "British Petroleum") adalah sebuah perusahaan minyak bumi bermarkas di London, dan salah satu 4 besar perusahaan minyak di seluruh dunia (bersama dengan Shell, ExxonMobil, dan Total)."

$\begin{array}{rcc}\text { "Pada Desember 1998, } & \text { BP } \\ \text { bergabung dengan American } & \text { Oil } \\ \text { Company (Amoco), membentuk } & \text { "BP }\end{array}$
Amoco". Namun, langkah ini dipandang umum sebagai sebuah pembelian Amoco oleh BP, hanya saja digambarkan secara resmi sebagai sebuah penggabungan karena alasan legal. Dan setelah setahun beroperasi bersama, mereka menggabungkan banyak operasi dan nama "Amoco" dilepas dari nama perusahaan. Divisi BP Solar telah menjadi pemimpin dalam produksi panel surya."

"BP juga merupakan partner pemimpin dalam jalur pipa Baku-TbilisiCeyhan yang kontroversial."

"Pada 20 April 2010 Deepwater Horizon meledak, mengakibatkan 11 orang meninggal, dan menyebabkan tumpahan minyak yang 


Kredo 4 (2020)
KREDO: Jurnal IImiah Bahasa dan Sastra
Terakreditasi Sinta 4 berdasarkan Keputusan
Direktorat Jenderal Penguatan Riset dan
$\begin{gathered}\text { Pengembangan, Kementerian Riset, Teknologi dan } \\ \text { Pendidikan Tinggi Republik Indonesia } \\ \text { Nomor: 23/E/KPT/2019. 08 Agustus 2019 } \\ \text { https://jurnal.umk.ac.id/index.php/kredo/index }\end{gathered}$

mengkontaminasi daerah yang luas dari lingkungan laut Amerika Serikat dan terus memiliki dampak serius pada kehidupan liar, industry perikanan lokal, dan pariwisata daerah. Pemerintah AS menyebut BP sebagai pihak yang bertanggung jawab atas insiden ini."

Berikut adalah teks informasi profil perusahaan Honda yang disajikan Wikipedia Inggris.

"Honda Motor Company, Ltd. (Japanese: 本田技研工業株式会社 Hepburn: Honda Giken Kōgyō KK, IPA: [honda] (About this soundlisten); /'hpndə/) is a Japanese public multinational conglomerate corporation primarily known as a manufacturer of automobiles, motorcycles, and power equipment."

"Honda has been the world's largest motorcycle manufacturer since 1959 , as well as the world's largest manufacturer of internal combustion engines measured by volume, producing more than 14 million internal combustion engines each year. Honda became the second-largest Japanese automobile manufacturer in 2001. Honda was the eighth largest automobile manufacturer in the world in 2015."

"Honda was the first Japanese automobile manufacturer to release a dedicated luxury brand, Acura, in 1986. Aside from their core automobile and motorcycle businesses, Honda also manufactures garden equipment, marine engines, personal watercraft and power generators, and other products. Since 1986, Honda has been involved with artificial intelligence/robotics research and released their ASIMO robot in 2000. They have also ventured into aerospace with the establishment of GE Honda
Aero Engines in 2004 and the Honda HA-420 HondaJet, which began production in 2012. Honda has three joint-ventures in China: Honda China, Dongfeng Honda, and Guangqi Honda."

"In 2013, Honda invested about $5.7 \%$ (US $\$ 6.8$ billion) of its revenues in research and development.[8] Also in 2013, Honda became the first Japanese automaker to be a net exporter from the United States, exporting 108,705 Honda and Acura models, while importing only 88,357."

Berikut adalah teks informasi profil perusahaan Honda yang disajikan Wikipedia Indonesia.

"Honda Motor Company, Ltd. (Japanese: 本田技研工業株式会社 Honda Giken Kōgyō Kabushiki-gaisha, Honda Technology Research Institute Company, Limited) Tentang suara ini dengar (bantuan-info) (TYO: 7267) adalah produsen mobil, truk, sepeda motor dan skuter asal Jepang. Mereka juga membuat kendaraan segala medan (ATV), generator listrik, mesin kelautan, dan peralatan taman."

"Honda didirikan pada 24 September 1948 oleh Soichiro Honda. Honda merupakan produsen sepeda motor terbesar di dunia sejak 1959, dan juga produsen mesin pembakaran dalam terbesar dengan produksi lebih dari 14 juta unit tiap tahun. Honda berhasil menggusur Nissan sebagai produsen mobil kedua terbesar di Jepang tahun 2001. Honda juga menggusur Chrysler, untuk menjadi pabrikan mobil terbesar keempat di pasar AS. Sekarang ini, Honda juga pabrikan mobil terbesar keenam di dunia. Pada 2004, perusahaan ini mulai memproduksi motor diesel, yang sangat tenang dan tidak 


Kredo 4 (2020)
KREDO: Jurnal IImiah Bahasa dan Sastra
Terakreditasi Sinta 4 berdasarkan Keputusan
Direktorat Jenderal Penguatan Riset dan
$\begin{gathered}\text { Pengembangan, Kementerian Riset, Teknologi dan } \\ \text { Pendidikan Tinggi Republik Indonesia } \\ \text { Nomor: 23/E/KPT/2019. 08 Agustus 2019 } \\ \text { https://jurnal.umk.ac.id/index.php/kredo/index }\end{gathered}$

membutuhkan penyaring untuk dapat melewati standar polusi."

"Honda merupakan pabrikan Jepang pertama yang meluncurkan merek mobil mewahnya, menggunakan merk Acura untuk mobil mewahnya di Amerika Utara. Mobil Honda terkenal dengan daya tahan dan jarang rusak. Honda di Indonesia paling terkenal dengan sepeda motornya."

"Honda bermarkas di Tokyo. Saham mereka diperdagangkan di Bursa Saham Tokyo, Bursa Saham New York, dan juga perdagangan di Osaka, Nagoya, Sapporo, Kyoto, Fukuoka, London, Paris dan Swiss. American Honda Motor Co., bermarkas di Torrance, California."

"Pada tahun 2013, Honda menginvestasikan sekitar $5,7 \%$ (US $\$ 6,8$ miliar) dari pendapatannya untuk penelitian dan pengembangan. Pada tahun 2013 pula, Honda menjadi produsen mobil Jepang pertama yang menjadi eksportir bersih dari Amerika Serikat, mengekspor 108.705 model Honda dan Acura, sementara mengimpor hanya 88.357."

Berikut adalah teks informasi profil perusahaan Unilever yang disajikan Wikipedia Inggris.

"Unilever is a British-Dutch transnational consumer goods company co-headquartered in London, United Kingdom, and Rotterdam, Netherlands. Its products include food and beverages (about 40 percent of its revenue), cleaning agents, beauty products, and personal care products. It is Europe's seventh most valuable company. Unilever is one of the oldest multinational companies; its products are available in around 190 countries."
"Unilever owns over 400 brands, with a turnover in 2017 of 53.7 billion euros, and thirteen brands with sales of over one billion euros: Axe/Lynx, Dove, Omo, Heartbrand ice creams, Hellmann's, Knorr, Lipton, Lux, Magnum, Rexona/Degree, Sunsilk and Surf. It is a dual-listed company consisting of Unilever plc, based in London, and Unilever N.V., based in Rotterdam. The two companies operate as a single business, with a common board of directors. Unilever is organised into four main divisions - Foods, Refreshment (beverages and ice cream), Home Care, and Beauty \& Personal Care. It has research and development facilities in the United Kingdom (two), the Netherlands, China, India and the United States."

"Unilever was founded on September 2, 1929, by the merger of the Dutch margarine producer Margarine Unie and the British soapmaker Lever Brothers. During the second half of the 20th century the company increasingly diversified from being a maker of products made of oils and fats, and expanded its operations worldwide. It has made numerous corporate acquisitions, including Lipton (1971), Brooke Bond (1984), ChesebroughPonds (1987), Best Foods (2000), Ben \& Jerry's (2000), Alberto-Culver (2010), Dollar Shave Club (2016) and Pukka Herbs (2017). Unilever divested its speciality chemicals businesses to ICI in 1997. In the 2010s, under leadership of Paul Polman, the company gradually shifted its focus towards health and beauty brands and away from food brands showing slow growth." 


Kredo 4 (2020)
KREDO: Jurnal IImiah Bahasa dan Sastra
Terakreditasi Sinta 4 berdasarkan Keputusan
Direktorat Jenderal Penguatan Riset dan
Pengembangan, Kementerian Riset, Teknologi dan
Pendidikan Tinggi Republik Indonesia
Nomor: 23/E/KPT/2019.08 Agustus 2019
https://jurnal.umk.ac.id/index.php/kredo/index

"Unilever plc has a primary listing on the London Stock Exchange and is a constituent of the FTSE 100 Index. Unilever N.V. has a primary listing on Euronext Amsterdam and is a constituent of the AEX index. The company is also a component of the Euro Stoxx 50 stock market index."

Berikut adalah teks informasi profil perusahaan Unilever yang disajikan Wikipedia Indonesia.

"Unilever (NYSE: UN; LSE: ULVR) adalah perusahaan multinasional yang berkantor pusat di Rotterdam, Belanda (dengan nama Unilever N.V.) dan London, Inggris (dengan nama Unilever plc.). Unilever memproduksi makanan, minuman, pembersih, dan juga perawatan tubuh. Unilever adalah produsen barang rumah tangga terbesar ketiga di dunia, jika didasarkan pada besarnya pendapatan pada tahun 2012, di belakang P\&G dan Nestlé. Unilever juga merupakan produsen olesan makanan (seperti margarin) terbesar di dunia. Unilever adalah salah satu perusahaan paling tua di dunia yang masih beroperasi, dan saat ini menjual produknya ke lebih dari 190 negara."

"Unilever memiliki lebih dari 400 merek dagang, dengan 14 merek diantaranya memiliki total penjualan lebih dari £1 milliar, yakni: Axe, Dove, Omo, Becel, Heartbrand, Hellmann's, Knorr, Lipton, Lux, Magnum, Rama, Rexona, Sunsilk dan Surf. L Unilever N.V. dan Unilever plc, beroperasi di bawah satu nama dan dipimpin oleh dewan direksi yang sama. Unilever dibagi menjadi empat divisi utama, yakni Makanan, Minuman dan Es Krim, Perawatan Rumah Tangga, dan
Perawatan Tubuh. Unilever memiliki pusat riset dan pengembangan di Inggris, Belanda, Tiongkok, India, dan Amerika Serikat."

"Kantor pusat Unilever N.V. di Rotterdam, Belanda. Unilever didirikan pada tahun 1930 sebagai hasil penggabungan dari produsen margarin asal Belanda, Margarine Unie dan produsen sabun asal Inggris, Lever Brothers. Selama paruh kedua dari abad ke-20, Unilever secara signifikan berdiversifikasi ke berbagai bidang bisnis dan juga berekspansi ke berbagai negara. Unilever juga membuat beberapa upaya akuisisi, termasuk Lipton (1971), Brooke Bond (1984), ChesebroughPonds (1987), Best Foods dan Ben \& Jerry's (2000), serta Alberto-Culver (2010). Pada _ecade 2010an, di bawah kepemimpinan Paul Polman, Unilever secara perlahan menggeser fokus bisnisnya ke bisnis kesehatan dan kecantikan, dari yang sebelumnya ke bisnis makanan, yang menunjukkan tren perlambatan pertumbuhan."

"Unilever N.V. melepas sahamnya di Euronext Amsterdam dan juga merupakan komponen indeks AEX. Sementara Unilever plc melepas sahamnya di London Stock Exchange dan juga merupakan komponen Indeks FTSE 100. Unilever plc. Juga merupakan komponen indeks Euro Stoxx 50."

Dari data yang telah diperoleh dan dilampirkan di atas, ditemukan sembilan teknik penerjemahan dalam Wikipedia Indonesia berdasar pada teknik penerjemahan menurut Molina dan Albir (2002) sebagai berikut. 


Kredo 4 (2020)
KREDO: Jurnal IImiah Bahasa dan Sastra
Terakreditasi Sinta 4 berdasarkan Keputusan
Direktorat Jenderal Penguatan Riset dan
Pengembangan, Kementerian Riset, Teknologi dan
Pendidikan Tinggi Republik Indonesia
Nomor: 23/E/KPT/2019.08 Agustus 2019
https://jurnal.umk.ac.id/index.php/kredo/index

\section{Adaptasi}

Adaptasi merupakan teknik menggantikan istilah budaya dalam bahasa sumber dengan istilah yang dimiliki atau kondisi dan situasi yang sama dalam istilah budaya dalam bahasa target. Artinya, penerjemah harus membuat situasi baru yang dapat dianggap setara atau sama baik dalam bahasa sumber maupun bahasa target. Teknik ini juga bisa disebut sebagai teknik padanan budaya.

Teknik adaptasi dapat dilihat pada Wikipedia dengan bahasa Indonesia dalam artikel profil perusahaan British Petroleum. Di dalamnya, penerjemah mendeskripsikan kembali kejadian atau peristiwa yang secara langsung menimpa perusahaan dan menyeret perusahaan dalam masalah lingkungan dan bertanggungjawab untuk memberikan ganti rugi bagi masyarakat sekitar atas peristiwa tersebut.

Informasi yang ditulis oleh Wikipedia Indonesia ini mengadaptasi informasi yang ditulis oleh Wikipedia dengan bahasa Inggris. Namun kelengkapan informasi lebih jelas disampaikan oleh Wikipedia dengan bahasa Inggris. Wikipedia dengan bahasa Indonesia hanya menulis kembali sebagian atau inti peristiwa saja.

\section{Pengurangan}

Pengurangan atau biasa disebut reduksi merupakan teknik mengurangi elemen-elemen tertentu dari bahasa sumber. Ini juga disebut eliminasi, kelalaian atau pengurangan yang menekan informasi bahasa sumber dalam bahasa target. Dalam menerjemahkan profil perusahaan, penerjemah menggunakan teknik 194 | Jurnal Kredo Vol. 4 No. 1 Oktober 2020 reduksi. Karena ada beberapa elemen yang tidak terlalu penting untuk diterjemahkan. Sehingga perlu mengurangi beberapa informasi.

Hal ini dapat dilihat dalam artikel Wikipedia dengan bahasa Inggris yang berisi profil perusahaan British Petroleum. Di sana, terdapat beberapa penjelasan lebih mandalam tentang perusahaan tersebut. Namun, itu tidak ditemukan dalam artikel Wikipedia dengan bahasa Indonesia. Hal ini juga terlihat jelas dari jumlah paragraf yang ada dalam artikel profil perusahaan dalam Wikipedia dengan bahasa Indonesia lebih sedikit dibandingkan dengan artikel profil perusahaan dalam Wikipedia dengan bahasa Inggris.

\section{Penambahan}

Penambahan merupakan teknik menyampaikan detail yang tidak dirumuskan atau dinyatakan dalam bahasa sumber. Ini bisa berupa informasi atau parafrase secara eksplisit. Sama halnya dengan penambahan atau perolehan, ini juga bisa disebut ekspansi gramatikal untuk kejelasan makna.

Teknik penerjemahan ini adalah teknik umum dalam menerjemahkan halhal budaya atau istilah tertentu. Teknik penerjemahan ini sangat membantu bagi target pembaca untuk memahami makna istilah tertentu dengan memberikan tambahan informasi.

Hal ini dapat ditemukan dalam Wikipedia dengan bahasa Indonesia dari artikel profil perusahaan Honda. Di dalamnya, terdapat tambahan informasi terkait tempat atau posisi markas besar Honda dan informasi mitra atau rekanan perusahaan yang berada di Amerika Serikat (AS) yang tidak ditemukan pada 


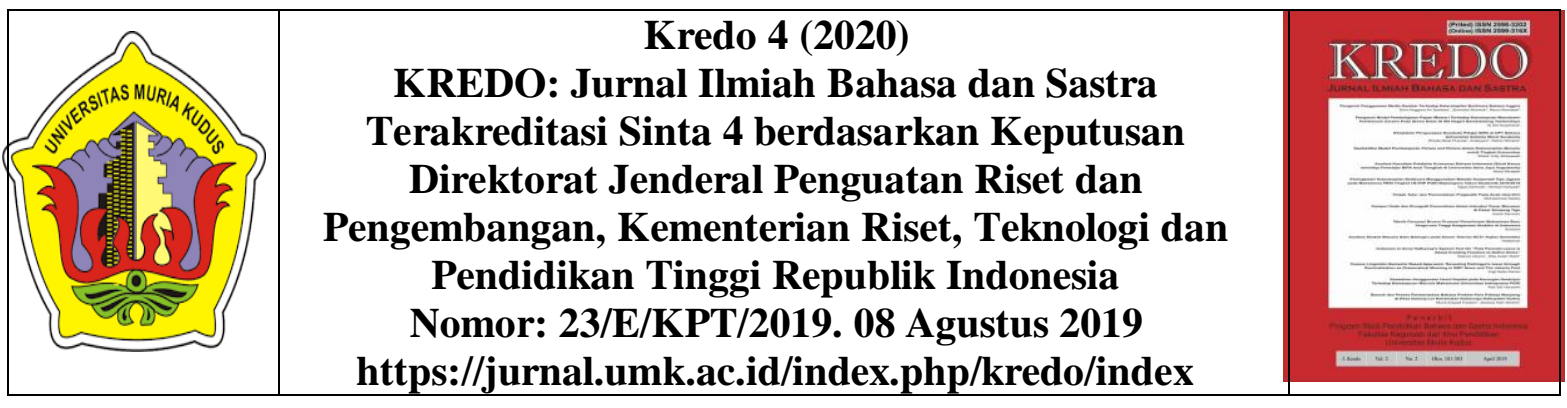

artikel profil perusahaan Honda dalam Wikipedia dengan bahasa Inggris.

\section{Peminjaman}

Meminjam merupakan teknik mengambil kata atau ungkapan langsung dari bahasa lain. Hal tersebut dapat dilakukan dengan disalin, direproduksi, diterjemahkan maupun diubah ke dalam bahasa terjemahan persis seperti dalam bahasa sumber. Ketika sebuah ekspresi atau kata diambil alih murni dalam bahasa terjemahan (tanpa perubahan) disebut pinjaman murni. Sedangkan dalam pinjaman yang dinaturalisasi, dapat dinaturalisasi agar sesuai dengan aturan ejaan dalam bahasa target (dengan perubahan).

Hal ini dapat dilihat pada teks deskripsi profil perusahaan Unilever dalam Wikipedia dengan bahasa Inggris dan Wikipedia dengan bahasa Indonesia. Di dalamnya, penerjemah menyebutkan olesan makanan dengan sebutan margarine. Di Indonesia sendiri, margarine biasa disebut mentega, tetapi dalam Wikipedia dengan bahasa Indonesia jelas menunjukkan bahwa kata margarine murni dipinjam dari bahasa aslinya ke bahasa target.

\section{Kalke}

Kalke juga disebut sebagai terjemahan pinjaman. Ini merupakan teknik terjemahan kata atau frasa atau bentuk bahasa sumber ke dalam bahasa target yang dapat berupa sistem leksikal atau struktural. Ini juga dapat diterjemahkan kata demi kata dalam suatu bahasa ke bahasa lain. Misalnya menerjemahkan setiap kata secara harfiah.
Hal ini dapat ditemukan pada artikel profil perusahaan Honda dalam Wikipedia dengan bahasa Indonesia. Di dalamnya, terdapat kata ATV atau kendaraan untuk segala medan. ATV merupakan kepanjangan dari All Terrain Vehicle yang berarti sebuah kendaraan roda empat yang dapat digunakan di tengah medan apa saja. Di Indonesia sendiri, ATV juga dimaknai dengan pemahaman yang sama sesuai dengan makna leksikalnya.

\section{Diskursif}

Diskursif adalah teknik yang menggantikan istilah atau ekspresi dengan deskripsi bentuk atau fungsinya. Tujuan dari teknik ini adalah untuk menunjukkan kesetaraan. Di sisi lain, kreasi diskurtif juga menggunakan padanan yang keluar konteks. Hal ini dimaksudkan untuk menarik perhatian pembaca.

Teknik ini juga ditemukan dalam Wikipedia dengan bahasa Indonesia dalam menerjemahkan istilah-istilah perusahaan atau nama-nama benda. Sebagian besar, istilah perusahaan dan nama benda atau penyebutannya diterjemahkan dengan menggunakan teknik pinjaman.

\section{Padanan}

Padanan merupakan teknik yang menggunakan istilah atau ekspresi yang diakui (dalam kamus atau bahasa yang digunakan dan penggunaan sehari-hari) sebagai setara dalam bahasa target. Ini digunakan untuk merujuk pada kasus di mana bahasa menggambarkan situasi yang sama oleh gaya atau struktur yang berbeda. 


Kredo 4 (2020)
KREDO: Jurnal Ilmiah Bahasa dan Sastra
Terakreditasi Sinta 4 berdasarkan Keputusan
Direktorat Jenderal Penguatan Riset dan
Pengembangan, Kementerian Riset, Teknologi dan
Pendidikan Tinggi Republik Indonesia
Nomor: 23/E/KPT/2019. 08 Agustus 2019
https://jurnal.umk.ac.id/index.php/kredo/index

Teknik ini ditemukan di ketiga artikel profil perusahaan dalam Wikipedia dengan bahasa Indonesia. Pasalnya, informasi ketiga profil perusahaan dalam bahasa Indonesia dirasa sangat komunikatif bagi pembacanya.

\section{Terjemahan Literal}

Terjemahan literal merupakan teknik penerjemahan dengan menerjemahkan kata atau ungkapan kata demi kata. Bahasa sumber diterjemahkan secara harfiah dan berfokus pada bentuk dan struktur, tanpa penambahan atau pengurangan ke dalam bahasa target. Hal ini dimaksudkan agar hasil terjemahan sesuai dan tepat sasaran mengingat dalam prosesnya telah berdasar pada fungsi dan makna dalam tataran kalimat. Hal ini dikarenakan, terjemahan harfiah cenderung sangat berpihak pada teks sumber.

Teknik terjemahan literal ditemukan dalam ketiga artikel profil perusahaan dalam Wikipedia dengan bahasa Indonesia. Di sini, penerjemah berfokus pada bahasa sumber yang memiliki bentuk dan struktur yang sama dengan bahasa target.

\section{Modulasi}

merupakan teknik mengubah sudut pandang dalam bahasa terjemahan untuk fokus dalam kaitannya dengan bahasa sumber. Teknik ini merupakan variasi dari bentuk informasi atau pesan, biasanya didapatkan dengan mengubah sudut pandang. Perubahan sudut pandang tersebut dapat bersifat leksikal maupun struktural. Teknik ini juga memungkinkan dalam mengekspresikan

196 | Jurnal Kredo Vol. 4 No. 1 Oktober 2020 fenomena yang sama dengan cara yang berbeda.

Terdapat dua teknik modulasi yang sering dijumpai pada proses penerjemahan. Yaitu modulasi standar dimana teknik ini bisa ditemukan pada kamus dengan dua bahasa. Selanjutnya adalah teknik modulasi bebas. Teknik satu ini cenderung lebih sering dijumpai dalam proses penerjemahan. Biasanya, teknik ini diterapkan karena penerjemah menemui sebuah makna tersirat, ambiguitas dan keterbatasan pilihan kata.

Teknik terjemahan ini digunakan oleh Wikipedia dengan bahasa Indonesia dalam menerjemahkan beberapa deskripsi kegiatan perusahaan.

Ketiga teks terjemahan dengan bahasa Indonesia ketiga profil perusahaan di atas, hampir semuanya menggunakan teknik penerjemahan yang hampir sama. Dari Sembilan teknik penerjemahan yang ditemukan, salah satu bahkan ketiga teks terjemahan menggunakannya. Hal ini berarti ketiga teks terjemahan mengalami proses penerjemahan yang sama karena memiliki target yang sama, yaitu masyarakat Indonesia.

Selain ketiga perusahaan multinasional di atas, di Indonesia sendiri, hampir semua lembaga pemerintah telah memiliki nama terjemahan resmi dalam bahasa Inggris. Bahkan, Indonesia juga menerjemahkan lembaga negara yang berdiri secara independen, seperti Bank Indonesia (BI), Otoritas Jasa Keuangan (OJK), dan PT Kustodian Sentral Efek Indonesia (KSEI) ke dalam terjemahan resmi bahasa Inggris. Tentu saja tidak hanya nama, tetapi informasi terkait lembaga pemerintah atau biasa disebut dengan 


Kredo 4 (2020)
KREDO: Jurnal IImiah Bahasa dan Sastra
Terakreditasi Sinta 4 berdasarkan Keputusan
Direktorat Jenderal Penguatan Riset dan
Pengembangan, Kementerian Riset, Teknologi dan
Pendidikan Tinggi Republik Indonesia
Nomor: 23/E/KPT/2019.08 Agustus 2019
https://jurnal.umk.ac.id/index.php/kredo/index

profil perusahaan juga diterjemahkan ke dalam bahasa Inggris.

Menurut situs web Kementerian Hukum dan Hak Asasi Manusia, tujuan menerjemahkan nama-nama tersebut adalah untuk membuat investor internas ional dan asing memahami institusi yang berwenang dan terlebih lagi sebagai dasar dalam perjanjian hukum (Kemenkumham 2019).

Sementara, menurut Newmark (1998), kehidupan politik dan sosial negara tertentu diwakili melalui istilah institusionalnya (Newmark 1998). Oleh karena itu, dalam menerjemahkan institusi atau lembaga terkait diperlukan adanya prosedur dan teknik penerjemahan. Istilah prosedur digunakan oleh Newmark (1988) dengan pengertian sebagai upaya penerjemah untuk mengatasi masalah-masalah yang muncul dalam penerjemahan. Misalnya dalam menerjemahkan tiga lembaga independen di bawah ini.

Pertama, Bank Indonesia (BI) atau Central Bank of the Republic of Indonesia.

Bank Indonesia diterjemahkan ke dalam bahasa Inggris menjadi Central Bank of Republik of Indonesia. Dalam hal ini, penerjemah tidak secara gamblang menerjemahkan Bank Indonesia menjadi Indonesian Bank. Penerjemah justru memberikan kata tambahan central untuk memperjelas posisi Bank Indonesia dan menambahkan kata republik seolah mempertegas status Bank Indonesia. Sehinga dapat disimpulkan bahwa penerjemah melakukan prosedur penerjemahan Newmark (1988) dalam menerjemahkan kata bermuatan budaya.
Dalam terjemahan ini, hasil terjemahan mengalami componential analysis. Pada umumnya, kata bermuatan budaya bahasa sumber memiliki makna yang lebih spesifik dibandingkan dengan bahasa sasaran. Untuk menghasilkan terjemahan yang mendekati bahasa sumbernya, penerjemah menambahkan komponenkomponen yang sesuai dengan bahasa sumbernya. Ketika mengunjungi situs webnya, pengunjung akan diberikan dua opsi di sisi kanan atas, apakah mereka ingin melihat situs web dalam Bahasa Indonesia atau Bahasa Inggris.

Bank Indonesia (BI) adalah bank sentral Republik Indonesia yang mempunyai tujuan tunggal, yaitu mencapai dan memelihara kestabilan nilai rupiah yang mengandung dua dimensi, yaitu kestabilan nilai mata uang terhadap barang dan jasa domestik (inflasi) dan kestabilan terhadap mata uang negara lain (kurs).

Oleh karena itu, penting bagi Bank Indonesia menyediakan akses bagi warga negara lain untuk mengetahui lembaga ini lebih jauh dengan menyediakan pilihan bahasa pada laman web-nya.

Kedua, Otoritas Jasa Keuangan (OJK) atau Financial Services Authority.

Penerjemah secara langsung menerjemahkan Otoritas Jasa Keuangan sesuai dengan kaidah penerjemahan ke dalam bahasa Inggris semestinya menjadi Financial Services Authority. Dalam hal ini, penerjemahan melakukan prosedur penerjemahan Newmark (1988) dalam menerjemahkan kata bermuatan budaya dengan standar Internasional atau accepted standard translation. Yaitu menggunakan terjemahan yang sudah 


Kredo 4 (2020)
KREDO: Jurnal IImiah Bahasa dan Sastra
Terakreditasi Sinta 4 berdasarkan Keputusan
Direktorat Jenderal Penguatan Riset dan
Pengembangan, Kementerian Riset, Teknologi dan
Pendidikan Tinggi Republik Indonesia
Nomor: 23/E/KPT/2019.08 Agustus 2019
https://jurnal.umk.ac.id/index.php/kredo/index

disepakati secara internasional Misalnya untuk istilah-istilah seperti Presiden, Senat, dan sebagainya.

Otoritas Jasa Keuangan (OJK) merupakan lembaga independen yang mempunyai fungsi, tugas, dan wewenang melakukan pengaturan, pengawasan, pemeriksaan, dan penyidikan. OJK dibentuk berdasarkan UU Nomor 21 Tahun 2011 yang berfungsi menyelenggarakan sistem pengaturan dan pengawasan yang terintegrasi terhadap keseluruhan kegiatan di dalam sektor jasa keuangan. Pengaturan dan pengawasan pasar modal dan lembaga keuangan, serta menggantikan peran Bank Indonesia dalam pengaturan dan pengawasan bank untuk melindungi konsumen industri jasa keuangan.

Oleh karena itu, penting bagi OJK menyediakan akses bagi warga negara lain untuk mengetahui lembaga ini lebih jauh dengan menyediakan pilihan bahasa pada laman web-nya.

Ketiga, PT Kustodian Sentral Efek Indonesia (KSEI) atau Indonesia Central Securities Depository.

Sama seperti OJK, penerjemah secara langsung menerjemahkan Kustodian Sentral Efek Indonesia sesuai dengan kaidah penerjemahan ke dalam bahasa Inggris semestinya menjadi Indonesia Central Securities Depository. Dalam hal ini, penerjemahan melakukan prosedur penerjemahan Newmark (1988:103) dalam menerjemahkan kata bermuatan budaya dengan standar Internasional atau accepted standard translation.

Dalam kelembagaan pasar modal di Indonesia, KSEI merupakan salah satu Organisasi Regulator Mandiri atau Self 198 | Jurnal Kredo Vol. 4 No. 1 Oktober 2020
Regulatory Organization (SRO), bersama dengan Bursa Efek dan Lembaga Kliring dan Penjaminan. KSEI menyediakan jasa kustodian sentral dan penyelesaian transaksi efek yang teratur, wajar dan efisien. KSEI juga memberikan layanan jasa yang meliputi administrasi rekening efek, penyelesaian transaksi efek, distribusi hasil corporate action dan jasa-jasa terkait lainnya, seperti post trade processing (PTP) dan penyediaan laporan-laporan jasa kustodian sentral.

Oleh karena itu, penting bagi KSEI menyediakan akses bagi warga negara lain untuk mengetahui lembaga ini lebih jauh dengan menyediakan pilihan bahasa pada laman web-nya.

Singkatnya, teori sosial dan budaya Newmark dapat diterapkan dalam menganalisis beberapa lembaga di Indonesia, seperti BI, OJK dan KSEI. Ketiga lembaga ini secara langsung juga berhubungan dengan kondisi luar negeri.

Oleh sebab itu, di situs web masingmasing lembaga tersebut masing-masing website menyediakan pilihan bahasa lain, yaitu bahasa Inggris sebagai opsi untuk mengetahui informasi tentang Indonesia. Di dalam situ web tersebut, terjemahannya juga mencerminkan kondisi di Indonesia dan bahasa terjemahan yang digunakan pun bertujuan untuk memperkenalkan, merangkul, dan membiasakan khalayak target nasional dan internasional dengan istilah BI, OJK dan KSEI itu sendiri.

\section{SIMPULAN}

Berdasarkan analisis data yang telah diuraikan pada subbab pembahasan, dapat disimpulkan bahwa terjemahan 


Kredo 4 (2020)
KREDO: Jurnal IImiah Bahasa dan Sastra
Terakreditasi Sinta 4 berdasarkan Keputusan
Direktorat Jenderal Penguatan Riset dan
$\begin{gathered}\text { Pengembangan, Kementerian Riset, Teknologi dan } \\ \text { Pendidikan Tinggi Republik Indonesia } \\ \text { Nomor: 23/E/KPT/2019. 08 Agustus 2019 } \\ \text { https://jurnal.umk.ac.id/index.php/kredo/index }\end{gathered}$

profil perusahaan di dalam Wikipedia Indonesia menggunakan sembilan teknik penerjemahan dari Molina dan Albir (2002). Masing-masing teknik hampir ditemukan di ketiga artikel profil perusahaan yang berbeda, yaitu British Petroleum, Unilever dan Honda.

Berdasarkan hasil analisis yang telah dilakukan dalam penelitian ini, menunjukkan adanya kompleksitas dalam pengertian terkait teknik penerjemahan. Sehingga perlu diperhatikan dan dimengerti.

Selain itu, berdasarkan hasil peniltian juga dapat disimpulkan bahwa penerjemah tidak bisa secara langsung begitu saja menerjemahkan profil perusahaan asing. Penerjemah memerlukan penambahan kata, pengurangan kata, padanan kata maupun peminjaman kata dan lain sebagainya untuk menerjemahkan profil perusahaan dari bahasa Inggris ke dalam bahasa Indonesia.

Jika melihat kembali artikel profil ketiga perusahaan dalam Wikipedia dengan bahasa Indonesia ini, hasil terjemahan dalam bahasa Indonesia cenderung lebih singkat dan padat dibandingkan dengan artikel dalam Wikipedia dengan bahasa Inggris. Hal ini menunjukkan banyak pengurangan informasi yang dirasa berlebihan oleh penerjemah.

Namun demikian pengurangan ini tidak mempengaruhi informasi utama ketiga perusahaan asing yang juga berdiri di Indonesia ini. Sehingga masyarakat Indonesia pun sudah mendapat informasi yang cukup tentang ketiga perusahaan ini dari artikel di Wikipedia dengan bahasa Indonesia.

\section{DAFTAR PUSTAKA}

Azizah, Fitria Puji Nur. 2019. "Teknik Penerjemahan KataKata Budaya pada Roman Das Parfum dari Bahasa Jerman ke dalam Bahasa Indonesia." Dalam Jurnal UGM, Volume 2 Nomor 1 halaman 32-40. Yogyakarta: Universitas Gajah Mada.

"British Petroleumt". Inggris-Wikipedia. Diakses pada 12 Desember 2019, dari: https://en.wikipedia.org/wiki/BP

"British Petroleumt". Indonesia-Wikipedia. Diakses pada 12 Desember 2019, dari: https://id.wikipedia.org/wiki/Bp

"Honda". Inggris-Wikipedia. Diakses pada 12 Desember 2019, dari: https://en.wikipedia.org/wiki/Honda

"Honda". Indonesia-Wikipedia. Diakses pada 12 Desember 2019, dari: https://id.wikipedia.org/wiki/Honda 


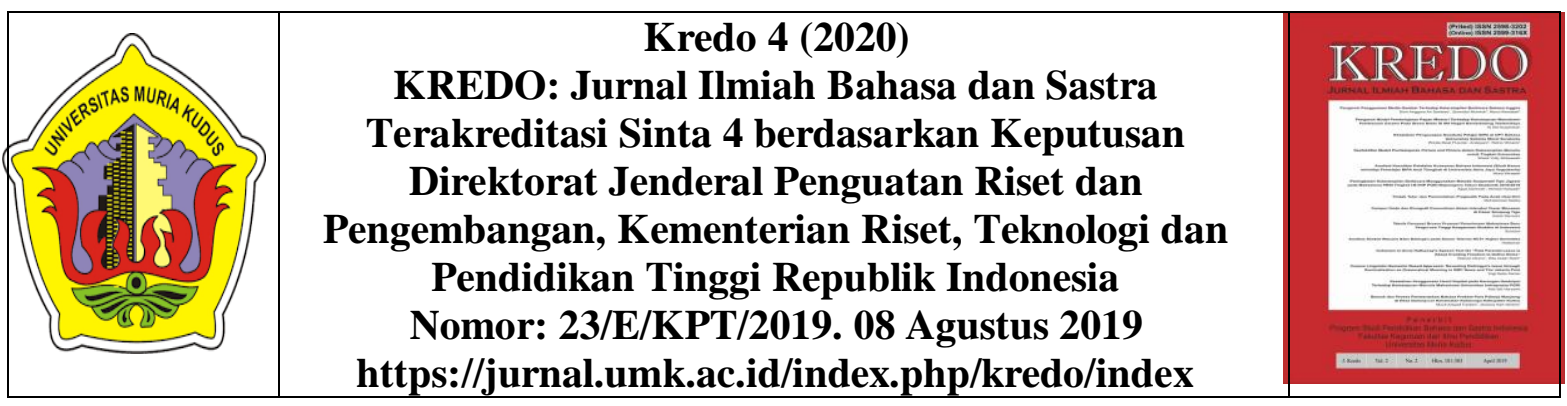

Molina, L dan Albir, A.H. 2002. "Translation Technique Revisted: A Dynamic and Functionalist Approach.” Dalam Jurnal META, Volume XLVII, No 4. Spain: Universitat Automana Barcelona.

Newmark, P. 1988. A textbook of translation. New York: Prentice Hall Inc.

Purwaningrum, Endang dan Hastuti Redayanita. 2016. “Analisis Penerjemahan: Studi Kasus Pada Penerjemahan Company Profile." Dalam Jurnal Epigram, Volume 13 Nomor 1. Depok: Politeknik Negeri Jakarta.

Pym, A. 2014. Exploring Translation Theories. London and New York: Routledge.

Raiss, Georgiana. 2015. Modulation in The Translation Process: The Same Meaning from a Different Perspective. A Bilingual EU Corpus-Based Analysis. Romania: University of Pitesti.

Taber \& Nida, E. A. 1964. The Theory and Practice of Translation. Leiden: E. J. Brill.

Vinay, J.P. dan Jean Darbelnet. 1995. Comparative Stylistic of French ang English: A Methodology for Translation. Amsterdam: John Benjamins Publishing Company.

“Unilever”. Inggris-Wikipedia. Diakses pada 12 Desember 2019, dari: https://en.wikipedia.org/wiki/Unilever

“Unilever”. Indonesia-Wikipedia. Diakses pada 12 Desember 2019, dari: https://id.wikipedia.org/wiki/Unilever

200 | Jurnal Kredo

Vol. 4 No. 1 Oktober 2020 